\title{
Identifikasi Potensi dan Status Pengembangan Desa Wisata di Kabupaten Lombok Tengah, Nusa Tenggara Barat
}

\author{
Identifying Potential and Development Status of Tourism Village Development \\ in Central Lombok Regency, West Nusa Tenggara
}

\author{
Azhar Amir ${ }^{1 *}$, Taufan Daniarta Sukarno ${ }^{1}$ \& Fauzi Rahmawati ${ }^{1}$ \\ ${ }^{1}$ Pusat Penelitian dan Pengembangan, Balilatfo, Kementerian Desa, Pembangunan Daerah Tertinggal dan \\ Transmigrasi, Jalan TMP Kalibata Nomor 17, Jakarta Selatan 12750; \\ *Penulis Korespondensi.e-mail: accabonsky13@gmail.com \\ (Diterima: 25 Januari 2020; Disetujui: 7 Mei 2020)
}

\begin{abstract}
Tourism village is a combination between natural attraction, culture, and local community creativity, supported by accommodation and other facilities that can attract tourists to visit. Central Lombok Regency is one of the regions that have many potential of tourism villages that yet to be developed. Its location is considered to be strategic and supported by the Special Economic Region (KEK) of Mandalika as government's super-priority destination. Tourism villages can be an alternative destination to support grand tourism project in Mandalika. The current problem is there is lack of information on tourism villages in Central Lombok Regency. This study aims to identify tourism village development potentials and classify the development status of tourism village in Central Lombok Regency. This research used mix-method approaches. Data collection used primary and secondary sources. Data were gained from interview, observation, questionnaire, and literature study. Data were analyzed using descriptive method, through scoring and classifying tourism village statuses. Result of this study shows that attraction and accessibility were the most important aspects to support tourism village development with scoring value of 3.1 and 3.3 respectively. Amenity, community readiness, and administrator had scoring value below 3. Village-owned enterprise (BUMDesa) and tourism awareness groups (Pokdarwis) are yet to support tourism village development. There are lack of promotions, thus needs to be supported by local government and agencies. Most of the villages in Central Lombok Regency were categorized as pioneer and developed. Only Sade village and Ende village were categorized as advanced, with main attraction of Sasak cultural heritage which was established several decades ago.
\end{abstract}

Keywords: development, Lombok, potential, status, tourism village

\begin{abstract}
ABSTRAK
Desa wisata merupakan paduan antara atraksi alam, budaya, dan kreativitas masyarakat setempat, didukung oleh akomodasi dan fasilitas lainnya, yang dapat menarik minat wisatawan untuk berkunjung. Kabupaten Lombok Tengah memiliki paduan potensi tersebut. Lombok Tengah mempunyai letak yang strategis dengan didukung keberadaan Kawasan Ekonomi Khusus (KEK) Mandalika sebagai destinasi pariwisata super prioritas. Desa wisata dapat menjadi alternatif tujuan wisata sebagai variasi pendukung Mandalika. Namun, informasi tentang desa wisata yang berada di Lombok Tengah masih terbatas. Studi ini bertujuan untuk mengidentifikasi potensi kondisi destinasi desa wisata dan mengklasifikasi status tahapan pengembangan desa wisata di Lombok
\end{abstract}


Tengah. Pendekatan penelitian menggunakan mix-method. Jenis data yang digunakan adalah data primer dan data sekunder. Data diperoleh dari wawancara, observasi, kuesioner, dan studi literatur. Data dianalisis menggunakan metode deskriptif, melalui pemberian skor dan klasifikasi status desa wisata. Hasil studi menunjukkan bahwa aspek atraksi dan aksesibilitas baik untuk mendukung dan pengembangan desa wisata dengan nilai skor masing-masing 3.1 dan 3.3. Aspek amenitas, kesiapan masyarakat, dan lembaga pengelola mempunyai nilai skor yang rendah kurang dari 3. Badan Usaha Milik Desa (BUMDesa) dan Kelompok Sadar Wisata belum optimal untuk mendukung keberlanjutan desa wisata. Begitu halnya dengan promosi yang belum berjalan dengan baik, sehingga dukungan dari pemerintah dan asosiasi sangat diperlukan. Status tahapan perkembangan desa wisata di Lombok Tengah berupa rintisan, berkembang, dan maju. Destinasi Desa Sade dan Desa Ende berstatus desa maju dengan atraksi adat budaya Suku Sasak. Desa tersebut sudah lama terbentuk dan dikunjungi oleh wisatawan nusantara dan wisatawan mancanegara.

Kata kunci: desa wisata, Lombok, perkembangan, potensi, status

\section{PENDAHULUAN}

Undang-Undang No. 6 Tahun 2014 tentang Desa, menegaskan bahwa desa diakui, dijamin hak asal-usul dan hak tradisionalnya di dalam pengaturan dan pengurusan masyarakat. Najiyati et al. (2019) menyatakan bahwa dana desa yang diberikan untuk membangun desa bertujuan meningkatkan kesejahteraan masyarakat, membangun sarana prasarana, dan pengembangan potensi ekonomi lokal. Salah satu prioritas penggunaan dana desa dalam skala ekonomi lokal adalah usaha desa wisata.

Dukungan dari pemerintah untuk memprioritaskan sektor pariwisata sangat baik. Pemerintah menetapkan 10 destinasi Kawasan Strategis Pariwisata Nasional (KSPN) atau disebut sebagai 10 Bali baru. Namun beberapa faktor-faktor pendukung belum maksimal maka diputuskan lagi 5 destinasi super prioritas yaitu 1) Danau Toba, 2) Borobudur, 3) Labuan Bajo, 4) Likupang, dan 5) Kawasan Ekonomi Khusus (KEK) Mandalika.

Penetapan KEK Mandalika diharapkan dapat menjadi katalis terhadap sektor pariwisata di Lombok yang selama kurun waktu 10 tahun terakhir ini mengalami perkembangan yang cukup baik. Masterplan pengembangan KEK Mandalika dipegang oleh PT Pengembangan Pariwisata Indonesia (Persero) atau dikenal juga sebagai Indonesia Tourism Development Corporation (ITDC). ITDC telah melakukan diskusi dengan desa yang masuk dalam KEK seperti desa kuta, desa mertak, desa sengkol dan desa sukadana. Hasil diskusi diperoleh program untuk mengatasi kebutuhan dasar masyarakat seperti infrastruktur, pertanian, peternakan, perikanan, pendidikan, kesehatan, pengembangan ekonomi dan usaha, serta kegiatan sosial budaya yang bertujuan memberdayakan masyarakat setempat, mengurangi kemiskinan serta meningkatkan pendapatan masyarakat setempat (ITDC, 2018).

Tujuan program ITDC tersebut sejalan dengan arah pembangunan desa dan pengembangan desa wisata. Hal ini menjadi kekuatan internal Lombok Tengah yang merupakan wilayah KEK Mandalika. Desa wisata yang telah ditetapkan di Lombok Tengah dapat menjadi alternatif dan variasi destinasi bagi wisatawan.

Beberapa penelitian terkait desa wisata di Lombok sebelumnya telah dilakukan. Penelitian Suprihatin \& Hailuddin (2016) tentang potensi pengembangan Desa Sade sebagai desa wisata di Lombok Tengah (Sade merupakan nama dusun Desa Rembitan), Permadi et al. (2018) tentang potensi desa wisata di Jerowaru, Lombok Timur dan Hasanah (2019) tentang kearifan lokal daya tarik wisata destinasi desa sade. Namun informasi tentang desa wisata di Lombok Tengah masih terbatas padahal potensi daya tarik wisatanya berupa alam, budaya dan kreativitas masyarakat berupa produk sangat menarik. 
Berdasarkan hal tersebut perlu dilakukan penelitian atau kajian tentang desa wisata di Lombok Tengah. Penelitian ini bertujuan untuk mengidentifikasi potensi destinasi dan klasifikasi status tahapan pengembangan desa wisata. Hasil penelitian diharapkan sebagai bahan pertimbangan untuk menyusun program pengembangan desa wisata di Kabupaten Lombok Tengah.

\section{METODOLOGI}

Penelitian dilaksanakan pada bulan September-Desember 2019, berlokasi di desadesa wisata di Kabupaten Lombok Tengah. Penentuan lokasi bersifat purposive, dengan pertimbangan peneliti melakukan penelitian pada 12 desa wisata yang berada di sekitar pusat KEK Mandalika, untuk mendapatkan gambaran tourism pattern antara Bandara Internasional Lombok, KEK Mandalika dan desa-desa sekitarnya. Desa yang dinyatakan sebagai responden diwakili oleh Kepala Desa atau yang mewakili.

Jenis data yang digunakan adalah data primer dan data sekunder dengan pendekatan penelitian menggunakan mix methods, yaitu metode kualitatif untuk mengkaji aspek kebijakan, kesiapan masyarakat dan pengelola desa wisata dan metode kuantitatif untuk mengkaji aspek pariwisata, Indeks Desa Membangun (IDM), kunjungan wisatawan.
Pengumpulan data untuk aspek kebijakan dan kesiapan masyarakat diperoleh melalui wawancara dengan informan dari unit kerja.

Kementerian PUPR, Bappenas, Kementerian Pariwisata, Dinas Pariwisata Kabupaten, Dinas Pemberdayaan Masyarakat Desa Kabupaten Lombok Tengah. Aspek pariwisata didapat melalui diskusi grup terfokus (FGD) dengan kepala desa, pengelola desa wisata, observasi lapang, dan pengisian kuesioner. Data dianalisis secara deskriptif dan scoring dimodifikasi dari penelitian Tyas \& Damayanti (2018). Penilaian skor didapat menggunakan pengisian kuesioner dan dinyatakan dalam indeks untuk aspek pariwisata seperti atraksi, amenity, aksesibilitas, kesadaran masyarakat dan lembaga pengelola desa wisata. Skor menggunakan modifikasi skala Likert dengan nilai $1-5$ dan rumus interval kelas sebagai berikut:

\section{Interval $=\frac{\text { Skor Tertinggi }- \text { Skor Terendah }}{\text { Jumlah Kelas }}$}

Atribut yang digunakan dalam penilaian skor dinyatakan dalam indeks pada masingmasing aspek dijelaskan pada Tabel 1 .

Tabel 1. Penilaian informan pada aspek desa wisata di Kab Lombok Tengah

\begin{tabular}{lllll}
\hline No & Aspek & Atribut & Skor & Keterangan \\
\hline 1 & Atraksi & Keindahan/Pesona & 1 & Sangat Tidak \\
& & 2 & Tidak \\
& & Kebersihan/Kenyamanan/Keamanan & Cukup \\
& & 4 & Sesuai \\
& & 5 & Sangat \\
& & Velestarian Lingkungan & (indah/bersih/nyaman/aman/ \\
& & & unik/baik/bervariasi) \\
\hline 2 & Amenitas & Rumah Makan/Restoran & 1 & Tidak ada \\
& & Homestay, saung/gazebo & Ada tapi tidak mendukung \\
& & Tempat Parkir, Papan Informasi & 3 & Cukup mendukung \\
& & 4 & Mendukung \\
& Tempat Pengelolaan Sampah & 5 & Sangat mendukung \\
\hline \multirow{2}{*}{ Aksesibilitas } & Mushollah/tempat ibadah \& Toilet & 1 & Sangat rusak \\
& Jalan menuju kawasan superprioritas & 2 & Tidak baik \\
& Jalan Desa & 3 & Cukup baik \\
& Jalan Lingkungan ke destinasi & 4 & Baik \\
& Angkutan Umum & 5 & Sangat Baik \\
\hline
\end{tabular}


Tabel 1. Lanjutan

\begin{tabular}{lllll}
\hline No & Aspek & Atribut & Skor & Keterangan \\
\hline 4 & Kesiapan & Kesadaran & 1 & Sangat tidak baik \\
& Masyarakat & Partisipasi & 2 & Tidak baik \\
& Keramahtamahan & 3 & Cukup baik \\
& & 4 & Baik \\
& & 5 & Sangat baik \\
\hline 5 & Lembaga & Tersedia Bumdes/Pokdarwis/lainnya & 1 & Sangat tidak baik \\
& Pengelola & Pemandu Wisata & 2 & Tidak baik \\
& & Pengemasan Paket Wisata & 3 & Cukup baik \\
& & Promosi Wisata & 4 & Baik \\
& & Dukungan/kerjasama dari luar & 5 & Sangat baik \\
\hline
\end{tabular}

Nilai indeks desa wisata diperoleh melalui rataan skor pada masing-masing desa dan klasifikasi skor dalam status desa wisata sesuai Kementerian Pariwisata (2019). Nilai indeks untuk status desa wisata disajikan pada Tabel 2.

Tabel 2. Total skor dan status desa wisata

\begin{tabular}{ll}
\hline Total skor & Status Desa Wisata \\
\hline $1.00-1.80$ & Tidak potensial \\
$1.81-2.60$ & Potensi / Rintisan \\
$2.61-3.40$ & Berkembang \\
$3.41-4.20$ & Maju \\
$4.21-5.00$ & Mandiri \\
\hline
\end{tabular}

\section{HASIL DAN PEMBAHASAN}

\section{Gambaran Umum Desa di Lombok Tengah}

Kabupaten Lombok Tengah mempunyai 127 desa pada 12 kecamatan. Dari 127 desa ini, terdapat $18 \%$ merupakan desa wisata yang ditetapkan sebagai desa wisata. Desa wisata ini diharapkan mampu meningkatkan pembangunan desa dari aspek sosial, ekonomi dan lingkungan. Perencanaan pengembangan wisata desa ini diupayakan untuk meningkatkan perekonomian masyarakat desa, mendorong tumbuhnya usaha pariwisata di desa, membuka lapangan kerja tanpa mengabaikan nilai-nilai adat sosial budaya dan merusak ekologi lingkungan di desa. Pada umumnya status desa memiliki Indeks Desa Membangun (IDM) kategori berkembang seperti pada Gambar 1 .

Rataan Indeks Ketahanan Sosial (IKS) desa-desa di Kabupaten Lombok Tengah memiliki indeks yang baik dengan nilai 0.7170 lebih tinggi dari IKS desa di Nusa Tenggara Barat dengan nilai 0.6502. Atribut modal sosial dan kesehatan berkontribusi pada nilai ini yang berarti bahwa tingginya solidaritas, toleransi dan keberdayaan masyarakat untuk kesehatan. Begitu halnya dengan rataan Indeks Ketahanan Lingkungan (IKL) cukup baik dengan nilai 0.6616 mengindikasikan pencemaran pada air, tanah dan udara tidak signifikan di Lombok Tengah. Pada sisi lain Indeks Ketahanan Ekonomi (IKE) memiliki nilai kurang baik, yaitu sebesar 0.5709. Kesenjangan nilai ekonomi sangat tinggi dengan range (min-max) 0.15-0.967. Pada IKE inilah yang umumnya membedakan status IDM desa (Muhtarom et al., 2018). Desa wisata diharapkan meningkatkan kegiatan ekonomi masyarakat desa. Hal tersebut menjadi pertanyaan apakah ada hubungan antara kunjungan wisatawan ke desa wisata dengan nilai ekonomi bagi suatu wilayah? (Adinugroho, 2017).

\section{Kebijakan Desa Wisata di Lombok Tengah}

Besarnya potensi sektor pariwisata, Pemerintah menetapkan 10 destinasi KSPN pada tahun 2015. Kemudian diputuskan lagi menjadi lima destinasi super prioritas. Salah satunya adalah KEK Mandalika yang terletak di Kec. Pujut Kabupaten Lombok Tengah. 


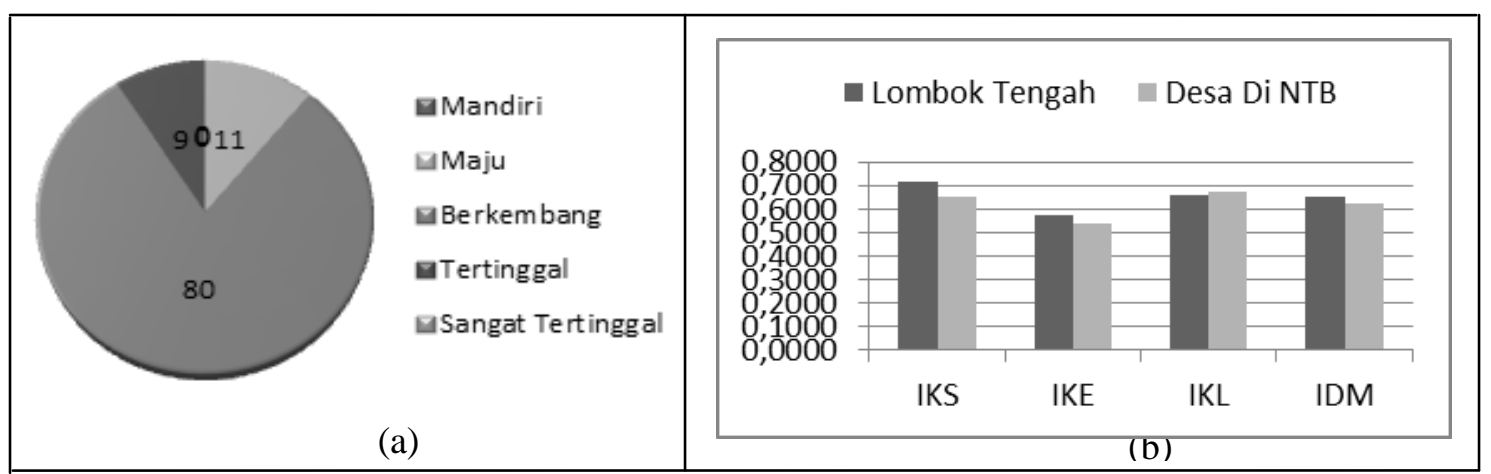

Gambar 1. (a) Persentase IDM Lombok Tengah; (b) Komparasi IDM Lombok Tengah dan NTB Ket= IKS : Indeks KetahananSosial; IKE : Indeks Ketahanan Ekonomi; IKL : Indeks Ketahanan Lingkungan; IDM : Indeks Desa Membangun.

Sumber : Kemendes PDT dan Trans, 2018, Diolah

Kawasan ini beririsan dengan beberapa desa yang memiliki potensi wisata seperti Desa Sengkol, Rembitan, Mertak dan Selong Belanak (Hakim et al., 2018). Sebagai tambahan dari laporan Estriani (2019) menyatakan bahwa dalam peluang dan tantangannya, KEK Mandalika harus bisa menjadi ajang untuk mempromosikan kearifan budaya lokal dengan turut menjaga keberlangsungan lingkungan hidup di desa-desa sekitarnya. Beberapa desa memiliki potensi wisata berupa alam, budaya dan kreativitas masyarakat di sekitar kawasan.

Kementerian Desa Pembangunan Daerah Tertinggal dan Transmigrasi (KemenDesa PDTT) melalui Peraturan Menteri No. 11 tahun 2019 tentang Prioritas Penggunaan Dana Desa Tahun 2020 (APBN) untuk usaha ekonomi desa salah satunya pembiayaan sarana prasarana desa wisata. Dukungan lainnya yang bersumber dari APBN berada di Kementerian/ Lembaga. KemenDesa PDTT, Kementerian Koperasi dan Usaha Kecil Menengah (KemenKop UKM) serta Kementerian Pariwisata dan Ekonomi Kreatif menyelenggarakan pelatihan pengelola desa wisata.

Pemerintah Provinsi Nusa Tenggara Barat juga merespon baik dengan menetapkan 99 Desa Wisata. Perencanaannya terintegrasi antara Kawasan Strategis Pariwisata Daerah (KSPD) dan desa wisata yang telah ditetapkan.
Di Lombok Tengah sebanyak 16 Desa yang juga bagian yang ditetapkan oleh kepala daerah sebagai desa wisata. Lombok Tengah telah menetapkan 22 Desa Wisata melalui Peraturan Bupati No. 176a Tahun 2018. Hasil FGD bahwa selanjutnya Pemerintah akan merevisi peraturan tersebut dan masih dalam proses pembahasan untuk menetapkan 23 Desa. Wisata. Terdapat desa yang diganti karena tidak berkembang dan desa yang memiliki potensi dan kemajuan dilanjutkan statusnya sebagai desa wisata. Atraksi berupa kreativitas dipertahankan serta ada tambahan atraksi wisata berbasis budaya dan alam.

\section{Potensi Pasar Pariwisata di Lombok Tengah}

Data kujungan wisatawan menunjukkan bahwa terdapat empat kawasan yang sering melakukan perjalanan ke pulau Lombok yaitu wisatawan dari Amerika, Eropa, ASEAN dan negara-negara Asia Pasifik lainnya. Wisatawan mancanegara (wisman) yang berasal dari Australia dan Eropa paling banyak berwisata ke Lombok. Destinasi Lombok umumnya didominasi kunjungan dari luar negeri namun pasar domestik menunjukkan tren yang meningkat (Bappeda NTB, 2019). Data Kunjungan wisatawan disajikan pada Gambar 2. 


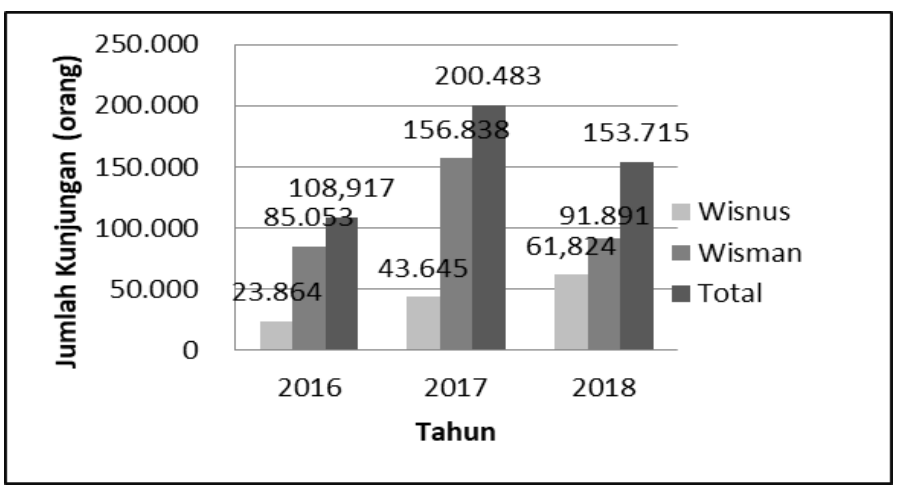

Gambar 2. Kunjungan wisatawan ke Lombok Tengah Sumber: BPS 2019, Diolah

Bappeda NTB, 2019 menyatakan bahwa destinasi wisata yang diminati wisman adalah atraksi alam, adat budaya lokal, paket bulan madu dan penyewaan kapal pesiar. Untuk wisatawan nusantara (wisnus) dengan kunjungan singkat, umumnya berasal dari Pulau Jawa, Bali dan Sulawesi. Wisnus tertarik pada wisata pantai, petualangan, Meeting, Incentive, Convention dan Exhibition (MICE), bulan madu, mengunjungi teman/keluarga dan budaya.

Potensi baru untuk kunjungan wisatawan ke pulau Lombok berasal dari negara Brasil, Rusia, India dan Cina yang disebut dengan istilah BRIC. Selain itu pada tahun mendatang, peningkatan kunjungan diharapkan berasal dari wisatawan Asia Tengah seiring diraihnya World Halal
Tourism Award 2016 di Abu Dhabi (Permadi et al., 2018).

\section{Aspek Pariwisata Desa Wisata}

Produk pariwisata merupakan komponen yang sangat penting dalam pariwisata. Hal tersebut berkaitan erat dengan pengelolaan destinasi, perbaikan sarana prasarana pendukung, manajemen lembaga pengelola, kesadaran dan partisipasi masyarakat secara langsung.

Pada tulisan ini telah dilakukan identifikasi potensi terkait dengan beberapa aspek di atas. Identifikasi tersebut dinyatakan dalam skor pengukuran. Indeks pengukuran desa wisata disajikan pada Tabel 3.

Tabel 3. Hasil Penilaian informan pada aspek potensi desa wisata di Kab. Lombok Tengah

\begin{tabular}{|c|c|c|c|c|}
\hline No & Aspek & Atribut & $\begin{array}{l}\text { Rerata } \\
\text { Skor }\end{array}$ & Keterangan \\
\hline \multirow[t]{6}{*}{1} & \multirow[t]{6}{*}{ Atraksi } & Keindahan/Pesona & 3.5 & \multirow{6}{*}{$\begin{array}{lrr}\text { Aspek atraksi } & \text { desa } \\
\text { wisata di } & \text { Lombok } \\
\text { Tengah } & & \text { cukup } \\
\text { mendukung } & \text { untuk } \\
\text { menarik } & \text { kunjungan } \\
\text { wisatawan } & & \\
\end{array}$} \\
\hline & & Kebersihan/Kenyamanan/Keamanan & 3.1 & \\
\hline & & Keunikan & 2.9 & \\
\hline & & Pelestarian Lingkungan & 2.9 & \\
\hline & & Variasi Kegiatan & 2.1 & \\
\hline & & Rerata Atraksi & 3.1 & \\
\hline \multirow[t]{8}{*}{2} & \multirow[t]{8}{*}{ Amenitas } & Rumah Makan/Restoran & 2.7 & \multirow{8}{*}{$\begin{array}{lr}\text { Sarana prasarana kurang } \\
\text { mendukung dalam } \\
\text { pengembangan } & \text { desa } \\
\text { wisata di } & \text { Lombok } \\
\text { Tengah } & \end{array}$} \\
\hline & & Homestay, Saung/Gazebo & 2.3 & \\
\hline & & Tempat Parkir & 2.8 & \\
\hline & & Papan Informasi & 3.0 & \\
\hline & & Tempat Pengelolaan Sampah & 1.3 & \\
\hline & & Mushollah/Tempat Ibadah & 2.9 & \\
\hline & & Toilet & 2.9 & \\
\hline & & Rerata Amenitas & 2.6 & \\
\hline \multirow[t]{5}{*}{3} & Aksesibilitas & Jalan Menuju Kawasan & 4.0 & \multirow{5}{*}{$\begin{array}{l}\text { Aksesibilitas } \\
\text { mendukung } \\
\text { pengembangan } \\
\text { wisata }\end{array}$} \\
\hline & & Jalan Desa & 3.8 & \\
\hline & & Jalan lingkungan ke destinasi & 3.3 & \\
\hline & & Angkutan Umum & 2.2 & \\
\hline & & Rerata Aksesibilitas & 3.3 & \\
\hline
\end{tabular}


Tabel 3. Lanjutan

\begin{tabular}{|c|c|c|c|c|}
\hline No & Aspek & Atribut & $\begin{array}{l}\text { Rerata } \\
\text { Skor }\end{array}$ & Keterangan \\
\hline 4 & $\begin{array}{l}\text { Kesiapan } \\
\text { Masyarakat }\end{array}$ & $\begin{array}{l}\text { Kesadaran } \\
\text { Partisipasi } \\
\text { Keramahtamahan } \\
\text { Rerata Kesiapan Masyarakat }\end{array}$ & $\begin{array}{l}2.6 \\
2.4 \\
3.6 \\
\mathbf{2 . 9}\end{array}$ & $\begin{array}{l}\text { Kesadaran dan } \\
\text { partisipasi melalui } \\
\text { pengembangan } \\
\text { kapasitas masyarakat } \\
\text { perlu ditingkatkan }\end{array}$ \\
\hline 5 & $\begin{array}{l}\text { Lembaga } \\
\text { Pengelola }\end{array}$ & $\begin{array}{l}\text { Tersedia Bumdes/Pokdarwis } \\
\text { Pemandu Wisata } \\
\text { Pengemasan paket wisata } \\
\text { Promosi Wisata } \\
\text { Dukungan/Kerjasama pihak lain } \\
\text { Rerata Lembaga Pengelola }\end{array}$ & $\begin{array}{l}2.5 \\
2.6 \\
2.6 \\
2.7 \\
2.4 \\
2.6\end{array}$ & $\begin{array}{lr}\text { Lembaga pengelola } \\
\text { belum optima dalam } \\
\text { pengembangan } \\
\text { wisata }\end{array}$ \\
\hline
\end{tabular}

\section{a) Atraksi}

Atraksi wisata merupakan salah satu komponen utama yang memberikan dorongan bagi wisatawan dalam melakukan aktivitas pariwisatanya. Atraksi wisata daya tarik yang memiliki nilai keindahan, keunikan, kekayaan alam, adat budaya dan kreativitas masyarakat yang menjadi destinasi kunjungan wisatawan. Atraksi wisata andalan di Lombok Tengah berupa wisata alam dan budaya serta didukung produk unggulan kerajinan tangan. Atraksi wisata alam seperti pantai, gunung, agrowisata hijau, air terjun memiliki pesona keindahan. Rata-rata nilai atraksi desa wisata di Lombok Tengah baik sebesar 3.1 dengan skor atraksi tertinggi pada Desa Sade di Desa Rembitan dan Desa Ende di Desa Sengkol dengan wisata budaya.

Atraksi wisata budaya banyak ditemukan di desa-desa yang masih dihuni oleh Suku Sasak yang mempertahankan kearifan lokal dan tradisi dengan baik secara turun temurun. Budaya kesenian Lombok Tengah beragam seperti tari duel peresean, gendang beliq, mi mertak, nyongkolan, tradisi ngumbuk (Kanom, 2015), tari marong, duel lutut anak, drama, festival tenun dan berbagai pertunjukan yang dapat menarik minat wisatawan. Dari produk kerajinan, di NTB dikenal penghasil gerabah di Desa Penujak dan penghasil tenun di Desa Sukarara.

Variasi kegiatan pada tujuan destinasi dianggap masih kurang baik. Seperti halnya di pantai, sebagian besar wisatawan mancanegara hanya berjemur dan berjalan menyusuri pantai. Begitu halnya atraksi budaya kesenian dan kerajinan, variasi kegiatan juga dianggap kurang. Hal ini perlu diperhatikan peran masyarakat dalam pengembangan kegiatan wisata yang perlu dilakukan untuk menghasilkan pendapatan ekonomi.

Brahmanto et al. (2017) menyatakan bahwa atraksi wisata yang unik merupakan faktor penentu dari motivasi wisatawan untuk berwisata, serta sebagai alasan penting yang menjadi pertimbangan mengapa seorang wisatawan memilih suatu destinasi. Atraksi wisata juga merupakan aspek yang menentukan kepuasan dan kenyamanan wisatawan yang akan berdampak secara ekonomi masyarakat terhadap keberlanjutan destinasi wisata.

b) Amenitas

Amenitas merupakan sarana dan prasarana yang mendukung suatu destinasi wisata yang diperlukan oleh wisatawan. Ratarata nilai amenitas Desa Wisata Lombok Tengah adalah 2.60 berkategori kurang mendukung pengembangan desa wisata. Hasil pengukuran skor amenitas terendah pada Desa Teruwai destinasi flying fox 1.14 dan nilai amenitas tertinggi pada Desa Kuta 3.57. Pada umumnya nilai amenitas Desa Wisata di Lombok Tengah masih rendah.

Desa Kuta memiliki amenitas tinggi karena sarana dan prasarananya disediakan oleh ITDC dan Desa Sade di Desa Rembitan yang sudah lama dikenal lama oleh wisman dan wisnus. Sedangkan Desa Wisata lainnya yang baru dibentuk masih memiliki nilai amenitas yang rendah. Nilai atribut yang cukup mendukung adalah papan informasi sedangkan atribut lainnya kurang mendukung. Selain itu 
ketersediaan homestay sebagai penginapan murah dengan fasilitas yang memadai masih sangat kurang. Data menunjukkan bahwa homestay paling banyak di Desa Kuta 150 unit sebagai pusat kawasan Mandalika dan bersaing dengan hotel untuk menarik minat wisatawan. Hasil FGD bahwa kebutuhan pada homestay cukup tinggi, persepsinya bahwa homestay tidak harus melalui pengadaan baru tapi dapat melakukan renovasi pada rumah warga untuk dijadikan penginapan layak bagi wisatawan.

Amenitas ini merupakan salah satu aspek penting yang berperan untuk menunjang kemudahan dan kenyamanan wisatawan dalam perjalanan wisata. Hasil studi Dwiputra (2013) menunjukkan bahwa preferensi wisatawan dalam memilih sarana wisata dipengaruhi oleh minat wisatawan berwisata, durasi wisatawan berwisata, dan teman wisatawan dalam melakukan perjalanan wisata. Lebih lanjut bahwa tidak semua destinasi wisata memerlukan sarana dan prasarana yang lengkap. Pengadaan amenitas ini disesuaikan dengan kebutuhan wisatawan. c) Aksesibilitas

Perjalanan menuju Pulau Lombok dapat diakses melalui jalur udara dan laut, dengan tiga pintu transportasi yakni Bandara Internasional Lombok (BIL), Pelabuhan Lembar, dan Pelabuhan Kayangan. BIL berada di Kecamatan Pujut Lombok Tengah sehingga wisatawan dapat dengan mudah mengakses desa wisata melalui kendaraan pribadi, penyewaan kendaraan, ojek online. Di Lombok Tengah belum ada trayek umum untuk mengangkut wisatawan ke desa wisata.

Nilai skor aksesibilitas di pulau Lombok sangat baik. Hasil pengukuran menunjukkan 3.0-3.75. Pembangunan akses yang baik dan keamanan jalan memberikan pengalaman yang nyaman bagi wisatawan.

Kemudian untuk jaringan jalan dan kondisi jalan agak lebar. Sebagian besar jalan yang ada di Kabupaten Lombok Tengah sudah diaspal dan hanya sebagian kecil saja yang permukaannya kerikil dan tanah. Adapun kondisi jalan pada lokasi kajian dapat dilihat pada Tabel 4.

Tabel 4. Kondisi jalan di lokasi desa wisata

\begin{tabular}{|c|c|c|c|c|c|c|}
\hline \multirow{2}{*}{ No } & \multirow{2}{*}{ Desa } & \multirow{2}{*}{ Kecamatan } & \multicolumn{3}{|c|}{ Kondisi Jalan (km) } & \multirow{2}{*}{ Total } \\
\hline & & & Aspal & Diperkeras & Tanah & \\
\hline 1 & Sukarara & Jonggat & 11 & 11 & 12 & 34 \\
\hline 2 & Tanak Beaq & Batukliang Utara & $\mathrm{Na}$ & na & $\mathrm{Na}$ & na \\
\hline 3 & Penujak & Praya Barat & 13 & 12 & 7 & 32 \\
\hline 4 & Setanggor & Praya Barat & 9 & 7 & 8 & 24 \\
\hline 5 & Mertak & Pujut & 17 & 3 & 78 & 98 \\
\hline 6 & Kuta & Pujut & 20 & 4 & 56 & 80 \\
\hline 7 & Rembitan & Pujut & 6 & 4 & 37 & 47 \\
\hline 8 & Sengkol & Pujut & 10 & 6 & 73 & 89 \\
\hline 9 & Teruwai & Pujut & 6 & 3 & 24 & 33 \\
\hline 10 & Marong & Praya Timur & 8 & 37 & 0 & 45 \\
\hline 11 & Selubung & Batukliang & $\mathrm{Na}$ & $\mathrm{Na}$ & $\mathrm{Na}$ & na \\
\hline 12 & Barabali & Batukliang & $\mathrm{Na}$ & $\mathrm{Na}$ & na & na \\
\hline
\end{tabular}

Keterangan: $\mathrm{Na}=$ data tidak tersedia

d) Kesiapan Masyarakat

Hasil pengukuran aspek kesadaran masyarakat di Lombok Tengah masih di bawah nilai 3.0, yaitu berkategori kurang. Pada umumnya nilai keramahtamahan sudah baik namun kepedulian, partisipasi dan kesiapan masyarakat sebagian besar rendah.

Destinasi Desa Sade dan Desa Ende memiliki nilai yang baik karena destinasi budaya sudah terbentuk sehingga kelompok masyarakat lebih sadar akan potensi budayanya. Beberapa penelitian seperti Fahham (2017), Gede et al. (2018), Permadi et al. (2018) menyatakan bahwa tantangan pengembangan pariwisata di Lombok berasal dari partisipasi masyarakat lokal, hal ini disebabkan oleh beberapa faktor seperti rendahnya pengetahuan dan kesadaran tentang kepariwisataan dan 
kurangnya pemberdayaan oleh pemerintah setempat.

Investasi pada sektor pariwisata di Lombok Tengah sebagian besar masih didominasi pendatang luar. Seperti halnya Desa Kuta sebagai pusat kawasan Mandalika, warga desa kurang diberdayakan sebagai tenaga kerja sektor pariwisata. Sebagian besar kebingungan dalam menentukan usaha apa yang harus diupayakan. Aparat Desa berkomitmen untuk tidak menjadi sebagai penonton di tengah kemajuan pengembangan pariwisata di kawasan Mandalika. Mereka berharap untuk memiliki kesempatan mengikuti pelatihan pariwisata sehingga penyerapan tenaga kerja banyak berasal dari warga lokal.

Antusiasme masyarakat lokal pada sektor pariwisata cukup tinggi, terutama dari sisi ekonomis. Hal ini tentunya menjadi modal yang berharga dalam membangun dan memperbaiki destinasi pariwisata di Pulau Lombok. Namun masyarakat pada umumnya masih sangat perlu untuk diberdayakan agar mampu menjadi penggerak kegiatan ekonomi di daerahnya masing-masing. Pelibatan tokoh masyarakat, tokoh agama dan tokoh adat sangat dibutuhkan dalam sistem pendidikan dan pelatihan tentang kepariwisataan di Lombok. Hal ini disebabkan oleh karakteristik masyarakat Lombok sendiri yang bersifat Paternalistik, yaitu cenderung untuk mengikuti arahan dan kata-kata dari pemimpin non formal atau seseorang yang dituakan di wilayahnya masing-masing.

Pendidikan dan pelatihan pariwisata juga perlu didukung oleh para pendidik di sekolahsekolah mulai dari tingkat dasar, menengah maupun atas. Pemerintah daerah perlu mengkaji ulang kurikulum pembelajaran daerah dengan menambahkan kepariwisataan dalam kurikulum muatan lokal, agar dapat memberi gambaran dan informasi awal kepada para murid demi meningkatkan kesadaran dan minat peserta didik untuk terlibat dalam dunia pariwisata.
Dari sisi pelatihan dibutuhkan tenaga kerja yang terampil dan memiliki sikap yang ramah pada wisatawan. Analisis kebutuhan pelatihan perlu dilakukan untuk mengetahui perencanaan dalam pengembangan desa wisata. Pelatihan yang bersifat parsial dan lama pelatihan yang singkat perlu dihindari, agar tenaga kerja yang dihasilkan memiliki daya serap yang tinggi. Pelatihan berbasis kompetensi pada pendamping desa, pengelola BUMDesa, Pokdarwis sangat dianjurkan agar memiliki pengetahuan, keterampilan dan sikap ramah pada wisatawan sehingga wisatawan merasa nyaman dan mempunyai pengalaman baik dalam mengunjungi desa wisata.

Solusi yang diajukan terhadap rendahnya partisipasi masyarakat dalam pengembangan desa wisata yaitu melalui konsep Community Based Tourism (CBT) (Hermawan, 2016; Brahmanto et al, 2017; Nugroho, 2017) menempatkan masyarakat sebagai subyek utama pembangunan dalam setiap aspek pengelolaan desa wisata, manfaat ekonomi pariwisata berupa tambahan pendapatan, peluang kerja dan usaha baru dapat terdistribusi secara merata kepada setiap lapisan masyarakat.

Giampiccoli \& Saayman (2018) menyatakan bahwa perlu ada klarifikasi konsep CBT bukan tentang partisipasi, jika partisipasi tersebut diajak dan dikendalikan secara eksternal. CBT dipahami mempunyai makna partisipasi yang artinya partisipasi diputuskan dan dilaksanakan oleh anggota masyarakat desa wisata. Pendekatan yang dilakukan oleh stakeholder umumnya bersifat top down yang dapat menekan tumbuhnya kesadaran dan partisipasi masyarakat. Pemerintah diharapkan memfasilitasi tahapan pengembangan desa wisata serta mensinergikan perkembangan usaha di pusat kawasan wisata daerahnya dengan tidak membiarkan desa wisata bersaing secara bebas dengan usaha wisata berskala besar. 
e) Lembaga Pengelola

Aspek lembaga pengelola mempunyai nilai yang rendah pada rata-rata 2.6. Keberadaan BUMDesa bisa disebut mati suri yang dapat menjadi penghambat dalam pengembangan desa wisata. Data Desa yang memiliki BUMDesa yaitu 55 dan jumlah yang aktif hanya 22 BUMDesa Adapun jenis usaha BUM Desa yang dimiliki oleh Desa Wisata yang ada di Lombok Tengah disajikan pada Tabel 5 berikut.

Tabel 5. Jumlah BUM Desa menurut Jenis Usaha di Lombok Tengah

\begin{tabular}{llll}
\hline No & Jenis Usaha & Jumlah & Persen (\%) \\
\hline 1 & Pertanian/peternakan/perkebunan/ perikanan & 5 & 14 \\
2 & Perdagangan & 5 & 14 \\
3 & Air Bersih & 4 & 11 \\
4 & Mengelola destinasi wisata & 3 & 9 \\
5 & Simpan Pinjam & 3 & 9 \\
6 & Penyewaan Terop/ Sound System & 3 & 9 \\
7 & Tata Boga/Kuliner & 2 & 6 \\
8 & Penyewaan Molen & 2 & 6 \\
9 & Mengelola promosi wisata & 2 & 6 \\
10 & Industri & 2 & 6 \\
11 & Jasa Pemasaran Online & 2 & 6 \\
12 & Mengelola Pasar Desa & 1 & 2 \\
13 & Percetakan & 1 & 2 \\
\hline
\end{tabular}

Kelompok sadar wisata (Pokdarwis) juga dianggap belum optimal menjalankan pengembangan destinasi wisata di Desa. Pemerintah daerah telah mengeluarkan penerbitan sebanyak 44 surat keputusan Pokdarwis. Dari jumlah tersebut, hanya 2 Pokdarwis yang berjalan mengembangkan paket wisatanya. Agar wisata desa dapat berjalan secara berkelanjutan dibutuhkan sinergi pengembangan daya tarik wisata, sarana prasarana yang memadai, akses yang baik, sumberdaya manusia pemandu wisata dan pengelola lembaga yang solid serta promosi untuk memajukan desanya untuk menghasilkan nilai ekonomi dan kesejahteraan.

Pemandu wisata lokal memiliki nilai ratarata 2.6 dengan kategori kurang mendukung pengembangan desa wisata. Antara et al. (2016) menyatakan bahwa seluk beluk tentang macam atraksi wisata, keunikan, dan sejarahnya hanya diketahui dengan baik oleh masyarakat desa. Untuk pengembangan desa wisata diperlukan pelatihan pemandu wisata yang kompeten, baik menyangkut pengetahuan pariwisata alam, budaya, dan buatan desa, maupun pelatihan bahasa asing serta pengetahuan dan praktek teknik-teknik pemanduan mengenai produk wisata yang ada di desa.

Indikator yang dapat menunjukkan keberhasilan suatu promosi pariwisata adalah jika destinasi tersebut mampu menarik minat calon wisatawan untuk membeli produk atau jasa wisata yang ditawarkan. Branding dan pengemasan produk wisata yang tepat serta memiliki ciri khas yang tidak dapat ditemukan di tempat lain akan menempatkan produk wisata tersebut selangkah lebih maju daripada produk wisata lainnya.

Penyusunan branding produk wisata perlu dilakukan kajian untuk memilih target pasar, dimana wisatawan memiliki karakter yang beragam yang akan mempengaruhi pengambilan keputusan mereka untuk berwisata sesuai selera masing-masing. Calon wisatawan perlu diberikan informasi yang lengkap terhadap destinasi wisata yang akan dituju agar sesuai keinginan dan tidak salah memilih tujuan wisata.

Skor pengemasan dan promosi masih rendah sebesar 2.6 dan 2.7. Promosi yang dapat ditempuh sebuah Desa Wisata antara lain melalui informasi yang dipublikasikan pada 
website Pemerintah Pusat, Provinsi, Daerah, media sosial dan biro perjalanan wisata. Antara et al. (2016) menyatakan bahwa prinsip promosi pariwisata yang baik adalah kejujuran (honesty) dan kepercayaan (trust). Paket wisata yang tidak sesuai dengan promosi akan menimbulkan kekecewaan bagi wisatawan dan akan menimbulkan testimoni yang kurang baik sehingga mempengaruhi calon wisatawan yang akan datang ke desa. Tidak kalah pentingnya, perlu kiranya para pemandu wisata dan penggerak wisata desa menggunakan teknologi informasi yang saat ini berkembang. Seperti halnya penggunaan sosial media yaitu twitter, facebook, instagram, youtube dan lainnya.

Kombinasi CBT, kearifan lokal dan pemanfaatan sosial media dapat meningkatkan pendapatan di tiga desa wisata yaitu Desa Nglanggeran, Desa Wisata Pulesari, Daerah Istimewa Yogyakarta dan Desa wisata Dieng Kulon, Jawa Tengah (Diharto et al., 2018). Hasil kajian menunjukkan bahwa pemanfaatan media online tersebut meningkatkan kunjungan wisnus dan wisman. Dampak positif dari kunjungan wisatawan ini dapat meningkatkan kesejahteraan masyarakat di desa wisata.

Pengelolaan suatu desa wisata melibatkan dukungan dan kerjasama dari berbagai pihak baik pemerintah, industri, dan biro perjalanan, asosiasi pariwisata yang secara holistik akan saling terkait dan jelas akan menimbulkan implikasi yang positif. Dukungan dan kerjasama ini semestinya memberikan pengaruh signifikan dalam pengembangan desa wisata dalam bentuk program pelatihan pengelolaan, pengetahuan dan keterampilan, hospitality, perbaikan sarana dan prasarana, bantuan promosi paket wisata. Saat ini nilai aspek dukungan dan kerjasama dari pemerintah serta badan usaha sebesar 2.4. Sampai saat ini, Desa Sade, Desa Ende, Desa Mertak dan Desa Setanggor telah memperoleh bantuan kerjasama dari Pemerintah Pusat untuk perbaikan amenitas di desanya.

\section{Indeks dan Status Desa Wisata di Lombok Tengah}

Proses pengembangan desa wisata memerlukan kajian tentang identifikasi kekuatan dan kelemahannya sehingga dalam pengambilan strategi dapat dilakukan dan tepat sasaran. Analisis skor menunjukkan identifikasi desa wisata pada beberapa aspek. Atraksi dan aksesibilitas memiliki nilai yang baik namun amenitas, kesiapan masyarakat dan lembaga pengelola masih mempunyai nilai rendah.

Peran serta masyarakat sangat diharapkan sebagai pengelola utama untuk mengidentifikasi masalah dalam pengembangan wisata di desanya. Kesadaran sapta pesona dan partisipasi masyarakat desa akan pariwisata perlu ditingkatkan untuk mengetahui status kemajuan desa. Status desa wisata disajikan pada Tabel 6 .

Tabel 6. Nilai indeks dan status desa wisata di Lombok Tengah

\begin{tabular}{llllll}
\hline \multirow{2}{*}{ No } & Desa & Kecamatan & \multicolumn{2}{l}{ Nilai Indeks dan Status Desa Wisata } \\
\cline { 4 - 5 } & & Destinasi & $\begin{array}{l}\text { Nilai } \\
\text { Indeks }\end{array}$ & Status \\
\hline 1 & Sukarara & Jonggat & Festival Tenun & 2.76 & Potensi/Rintisan \\
2 & Tanak Beaq & Batukliang Utara & Agro Buah Naga & 2.73 & Potensi/Rintisan \\
3 & Penujak & Praya Barat & Kreasi Gerabah & 2,62 & Potensi/Rintisan \\
4 & Setanggor & Praya Barat & Wisata Budaya & 3.05 & Berkembang \\
5 & Mertak & Pujut & Gunung Tunak & 2.75 & Potensi/Rintisan \\
6 & Kuta & Pujut & Pantai Kuta & 3.03 & Berkembang \\
7 & Rembitan & Pujut & Desa Sade & 3.41 & Maju \\
8 & Sengkol & Pujut & Desa Ende & 3.41 & Maju \\
9 & Teruwai & Pujut & Flying Fox & 2.37 & Potensi/Rintisan \\
10 & Marong & Praya Timur & Adat Budaya & 2.62 & Potensi/Rintisan \\
11 & Selubung & Batukliang & Agrowisata & 2.88 & Berkembang \\
12 & Barabali & Batukliang & Agrowisata & 2.74 & Berkembang \\
\hline
\end{tabular}


Status desa wisata di Lombok Tengah sebagian besar sebagai rintisan dengan Indeks Desa Wisata (IDW) pada rentang 1.81-2.60 pada 5 destinasi. Ciri-ciri desa wisata rintisan yaitu masih berupa potensi yang dikembangkan sebagai destinasi, sarana prasarana masih terbatas, masih sedikit pengunjung yang datang dan umumnya dari masyarakat sekitar, kesadaran masyarakat akan potensi belum tumbuh dan masih sangat butuh pendampingan dari pemerintah dan swasta. Strategi yang perlu dilakukan pada tahap Desa Wisata Rintisan ini adalah perbaikan sarana prasarana, peningkatan kapasitas masyarakat melalui pelatihanpelatihan seperti pengelolaan wisata, hospitality dan pemandu wisata.

Desa wisata dengan status berkembang berjumlah 4 destinasi yaitu Desa Setanggor destinasi wisata budaya, Desa Kuta destinasi pantai kuta, Desa Selebung destinasi agrowisata dan Desa Barabali destinasi agrowisata Gunung Selejan. Ciri-ciri desa wisata berkembang yaitu destinasi atraksinya sudah mulai dikenal dan dikunjungi masyarakat sekitar dan luar daerah, sudah terdapat fasilitas dan pengembangan sarana prasarana wisata, sudah tercipta lapangan kerja dan aktivitas ekonomi bagi masyarakat. Kesadaran masyarakat terhadap pariwisata mulai tumbuh dan masih memerlukan pendampingan dari tenaga ahli, pemerintah dan swasta sebagai fasilitator dalam pengembangan desa wisata.

Desa wisata dengan status maju yaitu Desa Sade di Desa Rembitan dan Desa Ende di Desa Sengkol. Kedua destinasi desa tersebut memiliki beragam atraksi budaya suku sasak yang memelihara dan melestarikan adat tradisi kehidupannya sejak turun temurun dari nenek moyang mereka mulai dari bentuk rumah, adat budaya hingga mata pencaharian. Untuk masuk ke perkampungan adat tersebut, tidak dikenakan tarif tetap namun berupa sumbangan secara sukarela.

Ciri-ciri desa wisata maju adalah masyarakat sudah sepenuhnya sadar akan potensi dan pengembangannya, sudah menjadi destinasi yang dikenal dan dikunjungi oleh wisnus dan wisman. Fasilitas sarana prasarana sudah memadai, masyarakat sudah berkemampuan untuk mengelola usaha wisatanya dan tidak terlalu tergantung dukungan kerjasama dari pihak terkait atau masyarakat sebagai subjek pelaku wisata dan dana dikelola secara mandiri. Meskipun demikian, pemerintah masih memberikan perhatian dengan memberikan bantuan modal yang digunakan sesuai kebutuhan masyarakatnya (Kemenpar, 2019).

Karakteristik desa maju sesuai dengan konsep CBT dengan ciri peran aktif masyarakat untuk mengelola usaha wisata di desa. Desa wisata rintisan dan berkembang untuk mencapai desa wisata maju diperlukan peningkatan keterampilan masyarakat desa dengan gerakan sadar wisata (sapta pesona dan pelayanan prima), eksplorasi potensi produk unggulan melalui pendidikan dan pelatihan pariwisata berbasis masyarakat. Hasil yang diharapkan dari pelatihan-pelatihan ini akan menumbuhkan partisipasi masyarakat untuk mengembangkan potensi wisata di desanya secara berkelanjutan.

Strategi-strategi yang diambil oleh stakeholder untuk mengembangkan desa wisata perlu memperhatikan kebutuhan masyarakat. Aspirasi masyarakat desa merupakan input penting dalam proses perencanaan dan implementasi pengembangan desa wisata. Sehingga diperlukan sinergi program yang bersifat top down dan bottom up. Sinergi ini mendukung prinsip CBT yang mengutamakan pentingnya partisipasi masyarakat desa mengembangkan potensi wisatanya (Bagus et $a l, 2019)$.

\section{KESIMPULAN DAN REKOMENDASI}

\section{Kesimpulan}

1. Identifikasi potensi Desa Wisata di Kabupaten Lombok Tengah berupa atraksi alam, budaya dan buatan atau kreativitas masyarakat desa. Nilai atraksi baik dengan nilai rata-rata 3.01 dengan destinasi budaya dianggap paling baik untuk menarik minat wisatawan. Atraksi adat budaya suku sasak menjaga keaslian, keunikan kehidupan sejak nenek moyang sampai sekarang. Atraksi 
yang perlu diperbaiki di Lombok Tengah adalah atribut variasi kegiatan agar wisatawan merasa nyaman dan betah berada di pedesaan.

2. Identifikasi aksesibilitas mendukung pengembangan desa wisata sedangkan amenitas, kesiapan masyarakat dan lembaga pengelola dinilai belum optimal. Beberapa aspek tersebut nilainya masih rendah kurang dari 3.0. Diperlukan strategi penguatan dalam aspek yang rendah ini sesuai kebutuhan masyarakat desa sebagai pengelola. Intervensi yang kuat diperlukan pada atribut promosi dan pelatihan pemandu wisata yang kompeten.

3. Pengembangan Desa Wisata di Lombok Tengah terdiri atas 3 status tahapan yaitu rintisan atau berpotensi, berkembang dan maju. Sebagian besar destinasi berada pada status rintisan karena desa wisata baru terbentuk dengan kunjungan dari masyarakat sekitar dan kesadaran masyarakat akan potensi wisatanya belum tumbuh. Terdapat 4 Desa Wisata dengan status berkembang seperti Desa Kuta, Desa Selebung dan Desa Barabali dengan atraksi alam dan Desa Setanggor dengan atraksi wisata budaya. Status Desa Wisata yang sudah maju dengan penerapan CBT pada atraksi budaya suku sasak Desa Sade di desa Rembitan dan Desa Ende di Desa Sengkol.

\section{Rekomendasi}

1. Kolaborasi pemangku kepentingan secara luas pemerintah pusat, daerah, asosiasi pariwisata, swasta dan desa sangat diperlukan demi mencapai pengembangan pariwisata berkelanjutan jangka panjang. Rekomendasi dari penulis untuk membentuk "Forum Desa Wisata" minimal di tingkat Kabupaten terkait untuk mengakomodir kebutuhan-kebutuhan fasilitas sarana prasarana pelatihan yang diperlukan oleh masyarakat desa sebagai pengelola wisata. Forum ini harus secara aktif melakukan rapat koordinasi di tingkat Daerah/Provinsi untuk menentukan arahan dan sasaran sesuai program pariwisata
Kementerian/Lembaga sampai dengan Daerah.

2. Penyelenggaraan pelatihan oleh Kementerian/ Lembaga jangan bersifat parsial. Pelatihan-pelatihan seperti peningkatan kapasitas BUMDesa baik dari segi unit ekonomi usaha, SDM, pemodalan, kelembagaan dapat dilakukan dengan baik dan terintegrasi antara pusat dan daerah. Begitu halnya dengan Pokdarwis yang membutuhkan legitimasi sebagai pemandu wisata, pengelola wisata, pengemasan dan promosi-promosi paket wisata melalui pelatihan berbasis kompetensi.

3. Skema pengembangan desa wisata harus masuk dalam program kegiatan perencanaan desa RPJMDes. Hal ini sangat perlu dilakukan untuk mengikat komitmen Pemerintah Desa dalam pengembangan desa wisata, meningkatkan pendapatan asli desa serta memastikan masyarakat untuk tahu program desa sehingga dapat mengawal pelaksanaannya.

\section{UCAPAN TERIMAKASIH}

Ucapan terima kasih kami sampaikan kepada Dinas Pemberdayaan Masyarakat Desa Kabupaten Lombok Tengah, Dinas Pariwisata Kabupaten Lombok Tengah, agen wisata, Indecon, Kepala Desa beserta dari 12 Desa Wisata terkait di Lombok Tengah sebagai enumerator dalam pengisian kuesioner, serta Pusat Penelitian dan Pengembangan Kementerian Desa, Pembangunan Daerah Tertinggal dan Transmigrasi yang telah membiayai penelitian ini melalui DIPA tahun 2019.

\section{DAFTAR PUSTAKA}

Adinugroho, G. (2017). Hubungan Perkembangan Wisata Terhadap Ekonomi Wilayah di Gunungkidul Selatan. Journal of Regional and Rural Development Planning (Jurnal Perencanaan Pembangunan Wilayah dan Perdesaan), 1 (1), 16-27. 
Antara, M., Satriawan, I. K., \& Nyoman, I. S. A. (2016). Panduan Tata Kelola Desa Wisata Kenderan. Pelawa Sari.

Badan Perencanaan dan Pembangunan Daerah Provinsi Nusa Tenggara Barat. (2019). Rencana Induk Pariwisata Berkelanjutan Pulau Lombok 2015-2019.

Sutresna, I. B, Suyana, U. I. M., Saskara, I. A. N., \& Setyari, N. P. W. (2019). Community Based Tourism As Sustainable Tourism Support. RJOAS, 10 (94), 70-78.

Brahmanto, E., Hermawan, H., \& Hamzah, F. (2017). Strategi Pengembangan Kampung Batu Malakasari Sebagai Daya Tarik Wisata Minat Khusus. Jurnal Media Wisata, 15 (2), 588-600.

Diharto, A. K., Ismail, Y., Iriantini, D. B., Wijaya, U., \& Murtadlo, M. B. (2018). The Role of Community Based Tourism Based on Local Wisdom Using Online. International Journal of Civil Engineering and Technology, 9 (2), 908 915.

Dwiputra, R. (2013). Preferensi Wisatawan Terhadap Sarana Wisata Di Kawasan Wisata Alam Erupsi Merapi. Journal of Regional and City Planning, 24 (1), 3548.

Estriani, H. N. (2019). Kawasan Ekonomi Khusus (KEK) Mandalika dalam Implementasi Konsep Pariwisata Berbasis Ecotourism: Peluang Dan Tantangan. Mandala: Jurnal Hubungan Internasional, 2 (1), 64-79.

Fahham, A. M. (2017). Tantangan Pengembangan Wisata Halal di Nusa Tenggara Barat. Aspirasi: Jurnal Masalah-Masalah Sosial, 8 (1), 65-79.

Giampiccoli, A., \& Saayman, M. (2018). Community-Based Tourism Development Model And Community Participation. African Journal of Hospitality, Tourism and Leisure, 7 (4), $1-27$.
Hakim, M., Hakim, A., Harahap, N., \& Hakim, L. (2018). Mandalika Tourism Specific Economic Zona, Lombok Tengah Regency, West Nusa Tenggara. Journal of Business and Management, 20 (10), 67-73.

Hasanah, R. (2019). Kearifan Lokal Sebagai Daya Tarik Wisata Budaya di Desa Sade Kabupaten Lombok Tengah. DESKOVI: Art and Design Journal, 2 (1), 45-52.

Hermawan, H. (2016). Dampak Pengembangan Desa Wisata Nglanggeran terhadap Ekonomi Masyarakat Lokal. Jurnal Pariwisata, 3 (2), 105-117.

I Putu Gede, Syech Idrus, I. N. S. (2018). Potensi Desa Gumantar di Kabupaten Lombok Utara sebagai Desa Wisata. Jurnal Perhotelan dan Pariwisata, 8 (1), 58-72.

Indonesian Tourism Development Corporation (Itdc). (2018). Rencana Pengembangan Masyarakat Adat (RPMA) Mandalika Urban and Tourism Infrastructure Project.

Kanom. (2015). Strategi Pengembangan Kuta Lombok Sebagai Destinasi Pariwisata Berkelanjutan. Jurnal Master Pariwisata (Jumpa), 1 (2), 25-42.

Kementerian Pariwisata. (2019). Buku Pedoman Desa Wisata.

Muhtarom, Kusuma, N., \& Purwanti, E. (2018). Analisis Indeks Desa Membangun untuk Mengetahui Pola Perkembangan Pembangunan Desa di Kecamatan Gadingrejo Kabupaten Pringsewu. Inovasi Pembangunan: Jurnal Kelitbangan, 6 (02), 179-190.

Najiyati, S. Rahmawati, E., Danarti, \& Slamet, R. T. S. S. (2019). Optimalisasi Manfaat Dana Desa dalam Mendukung Perekonomian Desa di Kabupaten Belitung dan Belitung Timur. Pusat Penelitian dan Pengembangan Kementerian Desa, PDT, dan Transmigrasi. 
Journal of Regional and Rural Development Planning (Jurnal Perencanaan Pembangunan Wilayah dan Perdesaan) Juni 2020, 4 (2): 84-98

Nugroho, D. S. (2017). Desa Wisata sebagai Community Based Tourism. Upajiwa Dewantara, 1 (2), 68-82.

Permadi, L. A., Asmony, T., Widiana, H., \& Hilmiati, H. (2018). Identifikasi Potensi Desa Wisata Di Kecamatan Jerowaru, Lombok Timur. Jurnal Pariwisata Terapan, 2 (1), 33-45.

Suprihatin, W. \& Hailuddin, H. (2016). Potensi Pengembangan Sade sebagai Desa Wisata Lombok. Jurnal Ekonomi dan Bisnis, 20 (2), 69-82.

Tyas, N. W. \& Damayanti, M. (2018). Potensi Pengembangan Desa Kliwonan sebagai Desa Wisata Batik di Kabupaten Sragen. Journal of Regional and Rural Development Planning (Jurnal Perencanaan Pembangunan Wilayah dan Perdesaan), 2 (1), 74-89. 